\title{
Socio-Economic and Educational Background of the Respondents of Madurai City
}

\author{
V. Chandirasekaran ${ }^{1} *$ and S. Sureshkumar ${ }^{2}$ \\ ${ }^{1}$ Livestock Farm Complex, Veterinary College and Research Institute, Namakkal, India \\ ${ }^{2}$ Department of Livestock Products Technology, Veterinary College and Research \\ Institute, Orathanadu, India \\ (TamilNadu Veterinary and Animal Sciences University, Chennai, India)
}

*Corresponding author

\section{A B S T R A C T}

\section{Keywords}

Social, Economic, Madurai, Education

Article Info

Accepted:

04 September 2019

Available Online:

10 October 2019
A study was carried out in Madurai, a tier-II city of Tamil Nadu with the objective to study the social and educational background of the respondents. Multistage sampling procedure was adopted to select 120 household respondents. Relevant data were collected through personal interview with the help of a pilot-tested interview schedule. An ex-post facto research design was adopted to find out the results. Socio-economic background of the respondents of Madurai City revealed that nearly 77.5 per of the respondents were in the age group of 30-50 and 70 per cent of the respondents were female. Majority ( 52.5 per cent) of the respondents fell in the income group of Rs. 30,000 -70,000/annum and only 12.5 per cent of the respondents earned more than Rs. 70000 per annum. Around 60 per cent of the sampled respondents were living in the nuclear type families. Respondents living in the own house (52.5 per cent) was less than those living in rented houses (47.5 per cent). Majority of the families had a family size of less than 5 members (60 per cent). Educational qualification of the highest numbers of respondents (35 per cent) was in the range up to primary school and none of the respondents were post graduates.

\section{Introduction}

The researcher wanted to survey the social environment and educational background of the Madurai city of Tamil nadu state of India. Madurai is the second largest city of Tamil Nadu. Madurai is surrounded by the Sirumalai hills in the north and the Nagamalai hills in the west. The river Vaigai flows through the Madurai city segregating it into almost two equal halves. Madurai is renowned for its rice, cotton, paddy and jasmine plantations. Farmers in Madurai supplement their income with other occupations such as dairy farming, 
poultry-farming, pottery, brick making, matweaving and carpentry. Madurai is located at $9.93^{\circ} \mathrm{N} 78.12^{\circ} \mathrm{E}$.

It encompasses an area of $147.99 \mathrm{~km}^{2}$. It has an average elevation of 101 metres. It is situated approximately at $454.8 \mathrm{kms}$ away from Chennai. Madurai is represented in the LA by five elected members for each of the five zone - West, East, North, South and Central. The city has a hot and dry climate for almost eight months a year. The Hottest months are March to July.

The city has a moderate climate during the months August to October, due to heavy rains and thunderstorms. It enjoys a cool climate for the remaining months.

The average rainfall received by Madurai is around $85.76 \mathrm{~cm}$. The temperature ranges from $18^{\circ} \mathrm{C}$ to $40^{\circ} \mathrm{C}$. As of 2011 India census, the population of Madurai stood at 3,038,252. The sex ratio was 990 per 1000 .

Madurai is well known to be an academic centre for learning, culture, literature, art, music and dance.

Madurai now boasts of 47 approved institutions of Madurai Kamaraj University in addition to seven polytechnical schools and five Industrial training institutes (ITIs); Madurai also has two government medical institutes and 11 paramedical institutes, seven engineering colleges, seven government law college, three teacher training institutes, two music colleges, three management institutes and 30 arts and sciences colleges.

Also, Madurai is also well-known for the agricultural college and research institute to provide agricultural education to aspirants in the southern districts of Tamil Nadu.
Compared to the national average of $72.99 \%$, the average literacy rate in Madurai is $83.45 \%$.

\section{Materials and Methods}

An ex-post facto research design was adopted to find out the social and educational background of the people of Madurai city of Tamil Nadu state. This city represent all traditions, religions, castes, etc. of the state. A sample of 120 respondents were selected by simple random sampling method and the data pertaining to the individuals profile were collected personally through pre-tested interview schedule and were analysed and discussed accordingly. The analyses of the data were carried out through conventional, tabular and functional methods using SPSS (2003) as described by Teklebrhan (2013).

\section{Results and Discussion}

The results are shown in table 1 . Nearly 77.5 per cent of the respondents were in the age group of 30-50 and 70 per cent of the respondents were female. Majority (52.5 per cent) of the respondents fell in the income group of Rs. 30,000 -70,000/annum and only 12.5 per cent of the respondents earned more than Rs.70000 per annum. Around 60 per cent of the sampled respondents were living in the nuclear type families. Respondents living in the own house (52.5 per cent) was higher than those living in rented houses (47.5 per cent). Majority of the families had a family size of less than 5 members ( 60 per cent).

Educational qualification of the highest numbers of respondents (35 per cent) was in the range up to primary school and none of the respondents were post graduates.

The limitations in this study were directly related to the truth in answering about the income of the respondents. 
Table.1 Social and educational background of the respondents of Madurai city

\begin{tabular}{|c|c|c|}
\hline Particulars & Frequency $\mathbf{n}=120$ & Percentage \\
\hline \multicolumn{3}{|l|}{ Age } \\
\hline Young $<30$ years & 15 & $12.5 \%$ \\
\hline Middle 30-50 yrs & 93 & $77.5 \%$ \\
\hline Old >50 yrs & 12 & $10.0 \%$ \\
\hline \multicolumn{3}{|l|}{ Sex } \\
\hline Male & 36 & $30.0 \%$ \\
\hline Female & 84 & $70.0 \%$ \\
\hline \multicolumn{3}{|l|}{ Income } \\
\hline Low (Rs. $<30,000 /$ annum) & 42 & $35.0 \%$ \\
\hline Medium( Rs. 30,000 -70,000/annum) & 63 & $52.5 \%$ \\
\hline High $(>70,000 /$ annum $)$ & 15 & $12.5 \%$ \\
\hline \multicolumn{3}{|l|}{ Type of Family } \\
\hline Nuclear & 72 & $60.0 \%$ \\
\hline Joint & 48 & $40.0 \%$ \\
\hline \multicolumn{3}{|l|}{ Type of Residence } \\
\hline Own house & 63 & $52.5 \%$ \\
\hline Rented house & 57 & $47.5 \%$ \\
\hline \multicolumn{3}{|l|}{ Family size } \\
\hline$<5$ members & 72 & $60.0 \%$ \\
\hline$>5$ members & 36 & $30.0 \%$ \\
\hline 5 members & 12 & $10.0 \%$ \\
\hline \multicolumn{3}{|l|}{ Education } \\
\hline Illiterate & 09 & $7.5 \%$ \\
\hline Upto Primary education & 42 & $35.0 \%$ \\
\hline Less than High school & 27 & $22.5 \%$ \\
\hline Equivalent to High school & 27 & $22.5 \%$ \\
\hline Degree holder & 15 & $12.5 \%$ \\
\hline Post-graduate & -- & -- \\
\hline
\end{tabular}

References

SPSS (Statistical Package for Social Sciences), 2003. Application Guide. SPSS Inc.
Teklebrhan, T. (2013). Journal of Microbiology, Biotechnology and Food Sciences, 2(3): 959-969.

How to cite this article:

Chandirasekaran, V. and Sureshkumar, S. 2019. Socio-Economic and Educational Background of the Respondents of Madurai City. Int.J.Curr.Microbiol.App.Sci. 8(10): 459-461. doi: https://doi.org/10.20546/ijcmas.2019.810.049 